\title{
Adrenocortical Carcinoma - Clinical Case
} \author{
Amaral $^{3}$, Valeriano Leite ${ }^{4}$ and Rui César ${ }^{1}$ \\ ${ }^{1}$ Endocrinology and Nutrition Service, Divino Espírito Santo Hospital, Portugal \\ ${ }^{2}$ General Surgery Service, Divino Espírito Santo Hospital, Portugal \\ ${ }^{3}$ Oncology Service, Divino Espírito Santo Hospital, Portugal \\ ${ }^{4}$ Endocrinology Service, Institute of Portuguese Oncology, Portugal
}

Regina Medeiros ${ }^{1 *}$, Isabel Sousa ${ }^{1}$, Inês Mendes ${ }^{1}$, Rita Carvalho ${ }^{1}$, Francisco Melo Bento ${ }^{2}$, Inês Leite ${ }^{2}$, Natacha

Submission: February 08, 2021; Published: February 11, 2021

*Corresponding author: Regina Saudade Medeiros, Endocrinology and Nutrition Service, Divino Espírito Santo Hospital, Portugal

\begin{abstract}
Adrenocortical carcinoma (CAC) is rare and aggressive. It may be functional, causing Cushing's syndrome and/or virilization or nonfunctional, presenting with abdominal/lumbar pain or an incidental finding. For the diagnosis, it is essential to evaluate the secretory activity of the tumor, given that the excess of steroidogenesis is revealed as its fingerprint, and the performance of CT, with complementary MRI and/or PET. Complete surgical removal is the only potentially curative treatment. Adjuvant treatment with mitotane, an adrenolytic drug, is recommended, in unresectable or relapsing cases it can also be associated with chemotherapy containing etoposide, doxorubicin and cisplastin. The main prognostic factors are complete resection, disease staging and the Ki proliferation index 67.
\end{abstract}

The authors describe the case of a 41-year-old woman, followed in an Endocrinology consultation for left lobectomy and isthmectomy (adenomatoid goiter), who developed virilization and cushingoid stigmas, with laboratory study indicative of hypercortisolism. In this context, CT was performed revealing an atypical formation in the left adrenal gland with $14 \mathrm{~cm}$, resulting in deviation of the homolateral kidney, suggestive of adrenocortical carcinoma without evidence of metastasis on MRI.

Adrenalectomy was performed by left subcostal laparotomy, confirming low grade adrenal cortex carcinoma (pT3NxM0, stage III, 2\% Ki67). She was referred to the Oncology consultation, presenting pulmonary and hepatic metastasis, started mitotane for palliation with a slow and progressive increase in the dose that was suspended due to the progression of the disease. Later, the patient resumed mitotane associated with carboplatin and etoposide, presenting infectious complications on the tenth day of chemotherapy. She was referred for Palliative Care consultation. In this patient, CAC progressed quickly to stage IV, despite complete resection, using mitotane with chemotherapy for palliation without success. However, there are cases described for preventing recurrence and improving survival with the use of mitotane and adjuvant chemotherapy.

Keywords: Adrenocortical Carcinoma; Mitotane; Cushing's syndrome; Virilization

Abbreviations: CAC: Adrenocortical Carcinoma; CT: Computed Tomography; MRI: Magnetic Resonance Imaging

\section{Introduction}

Adrenocortical carcinoma (CAC) represents only $0.02 \%$ of all neoplasms, with an approximate incidence of 1 to 2 cases/million people/year, although it can develop at any age, it has two peaks, before 5 years of age and in the age group between 40 to 50 years old. It is predominant in females (1.5-2.5:1), there are studies that suggest a proliferative effect of estrogen on adrenal neoplastic cells [1].
Most cases are sporadic, with a tumor progression model similar to colorectal cancer, it is common to find loss of heterozygosity in locus $17 \mathrm{p} 13$ where the tumor suppressor gene TP53 (mutated in one third of sporadic CACs) and others unidentified suppressor genes. Mutations of the CTNNB1 gene that cause activation of $\beta$-catenins and at the $11 \mathrm{p} 15$ locus that increase IFG-2 expression also play an important role in the 


\section{Journal of Gynecology and Women's Health}

development of adrenal carcinoma [2]. A minority of cases are hereditary, associated with syndromes, such as Li-Fraumeni, Beckwith-Wiedemann and MEN-1 [3].

Approximately $60 \%$ of the tumors have hypersecretion of steroids, causing symptoms of Cushing's syndrome, weight gain, weakness and violet streaks and/or symptoms of excess androgens: virilization, acne, hirsutism and menstrual irregularities. In a small group of men it presents as feminization, loss of libido, testicular atrophy, gynecomastia. Hyperaldosteronism is rare with hypokalemia and hypertension [1].The rest do not secrete enough hormones and are manifested by abdominal/low back pain due to the rapidly progressive mass effect, constitutional symptoms or may be incidentalomas [1].

The diagnostic gait should include the assessment of tumor secretory activity (Table 1) [4], which is also essential for monitoring recurrences and adrenal insufficiency after adrenalectomy, and computed tomography (CT) with magnetic resonance imaging (MRI), to assess local invasion and/or FDGPET, to distinguish adenoma and carcinoma [5]. Regarding fine needle aspiration biopsy its indication is controversial, it does not distinguish benign from malignant lesions, however it differentiates primary from secondary adrenal tumors, using markers such as $\alpha$-inhibin, melan A and SF-1[6] nevertheless its use is not recommended by ENSAT due to the high risk of complications, such as the spread of disease. Metastasis of adrenal carcinoma occurs to the liver, lungs, lymph nodes and bone, with thoracoabdominal CT and bone scintigraphy necessary for staging (Table 2) [7].

Table 1: Analytical evaluation in patients with suspected adrenocortical carcinoma.

\begin{tabular}{|c|c|c|c|}
\hline Hormonal Evaluation & & $\begin{array}{l}\text { Patient Values in Diag- } \\
\text { nosis }\end{array}$ & Reference Values \\
\hline \multirow{4}{*}{ Glucocorticoids } & Basal cortisol & $21.90 \mathrm{ug} / \mathrm{dL}$ & $3.70-19.40 \mathrm{ug} / \mathrm{dL}$ \\
\hline & Urinary cortisol (24h) & $617.40 \mathrm{ug} / 24 \mathrm{~h}$ & $4.30-176.00 \mathrm{ug} / 24 \mathrm{~h}$ \\
\hline & $\begin{array}{l}\text { Morning serum } \\
\text { adrenocorticotropic hormone } \\
\text { (ACTH) }\end{array}$ & $1.20 \mathrm{pg} / \mathrm{mL}$ & $7.20-63.30 \mathrm{pg} / \mathrm{mL}$ \\
\hline & Suppression test with $1 \mathrm{mg}$ dexamethasone & $\begin{array}{l}\text { Without braking } \\
(20.5 \mathrm{ug} / \mathrm{dL})\end{array}$ & \\
\hline \multirow{5}{*}{$\begin{array}{l}\text { Sex steroids and steroid } \\
\text { precursors }\end{array}$} & $17-\beta$-estradiol & $28.10 \mathrm{pg} / \mathrm{mL}$ & $\begin{array}{c}\text { Follicular phase: } 37.00-1101.00 \mathrm{pmol} / \mathrm{L} \\
\text { Ovulation: } 550.00- \\
2202.00 \mathrm{pmol} / \mathrm{L} \\
\text { Luteal phase: } 183.00 \\
-1101.00 \mathrm{pmol} / \mathrm{L}\end{array}$ \\
\hline & $\begin{array}{l}\text { 17-hidroxi-progesterone (17- } \\
\text { OH-P) }\end{array}$ & $5.91 \mathrm{ng} / \mathrm{mL}$ & $0.18-1.05 \mathrm{ng} / \mathrm{mL}$ \\
\hline & Delta-4-androstenedione & $>10.0 \mathrm{ng} / \mathrm{mL}$ & $0.4-4.5 \mathrm{ng} / \mathrm{mL}$ \\
\hline & $\begin{array}{l}\text { Dehydroepiandrostenedione sulfate } \\
\text { (DHEA-S) }\end{array}$ & $839.9 \mathrm{ug} / \mathrm{dL}$ & $60.90-337.00 \mathrm{ug} / \mathrm{dL}$ \\
\hline & Free testosterone & $6.25 \mathrm{pg} / \mathrm{mL}$ & $\begin{array}{c}\text { Follicular phase: } 0.20 \\
-1.70 \mathrm{ng} / \mathrm{dL} \\
\text { Ovulation: } 0.30- \\
2.30 \mathrm{ng} / \mathrm{dL} \\
\text { Luteal phase: } 0.17 \text { - } \\
1.90 \mathrm{ng} / \mathrm{dL} \\
\text { Post menopause: } \\
0.20-2.06 \mathrm{ng} / \mathrm{dL}\end{array}$ \\
\hline \multirow{2}{*}{ Mineralocorticoids } & Potassium & $3.76 \mathrm{mmol} / \mathrm{L}$ & $3,50-5.10 \mathrm{mmol} / \mathrm{L}$ \\
\hline & Aldosterone / renin ratio & 0.37 & $<3.70$ \\
\hline \multirow{2}{*}{$\begin{array}{l}\text { Pheochromocytoma } \\
\text { exclusion }\end{array}$} & $\begin{array}{l}\text { Urinary vanillmandelic acid } \\
\text { (AVM) }(24 \mathrm{~h})\end{array}$ & $6.00 \mathrm{mg} / 24 \mathrm{~h}$ & $<13.60$ \\
\hline & $\begin{array}{l}\text { Total urinary metanephrines } \\
\qquad(24 \mathrm{~h})\end{array}$ & $244.00 \mathrm{mcg} / 24 \mathrm{~h}$ & $<785.00$ \\
\hline
\end{tabular}

ACTH: Table Abbreviations; ACTH: Adrenocorticotropic Hormone; 17-OH-P: 17-Hidroxi-Progesterone; DHEA-S: Dehydroepiandrostenedione Sulfate; AVM: Vanillmandelic Acid. 
Table 2: Staging according to the European Network for the Study of Adrenal Tumors 2008 and associated survival according to the study Fassnacht et al. [9]

\begin{tabular}{|c|c|c|}
\hline Stage & $\begin{array}{c}\text { European Network for the } \\
\text { Study of Adrenal Tumors }\end{array}$ & $\begin{array}{c}\text { 5-year survival (Fassnacht et } \\
\text { al.[9] }\end{array}$ \\
\hline I & T1, N0, M0 & $82 \%$ \\
\hline II & T2, N0, M0 & $61 \%$ \\
\hline III & T3-4, N0, M0 & $50 \%$ \\
\hline IV & T1-4, N1, M0 & $13 \%$ \\
\hline
\end{tabular}

Table abbreviations: T, Tumor; N, Lymph node; M, Metastasis.

\section{Clinical Report}

The authors describe the case of a 41-year-old woman, regularly followed in an Endocrinology consultation, since 2013 for left lobectomy and isthmectomy for adenomatoid goiter and obesity. In September 2019 she presented a fifteen-kilogram weight gain, alopecia, hirsutism, violet streaks, secondary amenorrhea with about 6 months of evolution (Figure 1).
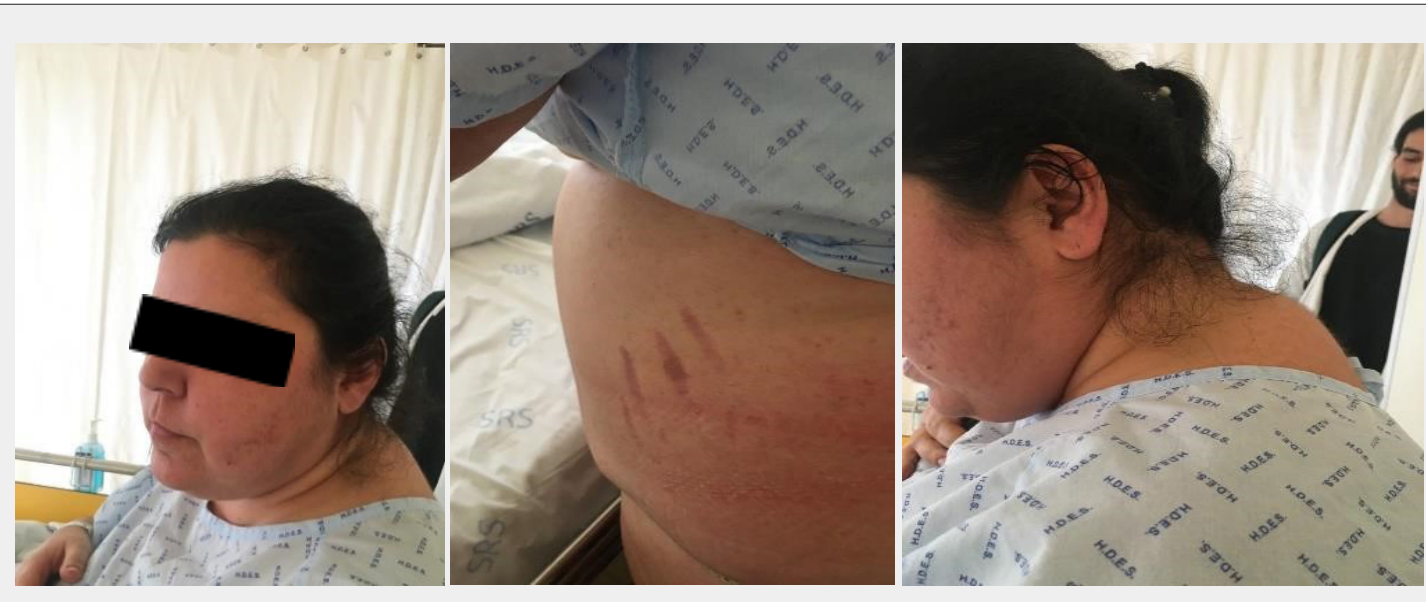

Figure 1- Phenotype of the patient in September 2019.

\section{Result}

The hormonal evaluation carried out in this context revealed hypercortisolism with emphasis on reduced adrenocorticotropic hormone, elevated urinary cortisol, without suppression in the braking tests with $1 \mathrm{mg}$ dexamethasone and Liddle's test. 17-hydroxyprogesterone, delta-4-androstenedione, free hydroxydiandrostenedione and testosterone-free hydroxyprone were increased (Table 1). In this context, in October 2019, a thoracoabdominopelvic CT scan revealed an atypical formation in the left suprarenal gland measuring $13.5 \times 8.5 \times 8.0 \mathrm{~cm}$, with calcifications and heterogeneous contrast uptake, causing deviation of the homolateral kidney, being suggestive of cortical adrenal carcinoma, confirmed in MR and without secondary lesions [8].
In January 2020, the patient was submitted to an adrenalectomy by left subcostal laparotomy. Histologically, low grade adrenal cortex carcinoma (pT3NxM0, stage III, 2\% Ki67) was observed. The patient kept the follow up in General Surgery and Endocrinology consultation. On a control CT scan done in February 2020, the patient had a hypodense left renal mass measuring $5.5 \times 4.2 \times 5.4 \mathrm{~cm}$, hepatic parenchymal nodular images hypodense in the left lobe segment IV with 1.8 and $1.4 \mathrm{~cm}$, a nodule with $1.2 \mathrm{~cm}$, adjacent to the right lobar hepatic capsule and several pulmonary parenchymal nodules at both bases, with dimensions between 0.7 and $1.4 \mathrm{~cm}$ (Figure 2). Findings suggested tumor recurrence/remnant associated with liver and lung metastasis, however, analytically without evidence of secretory activity [9]. 

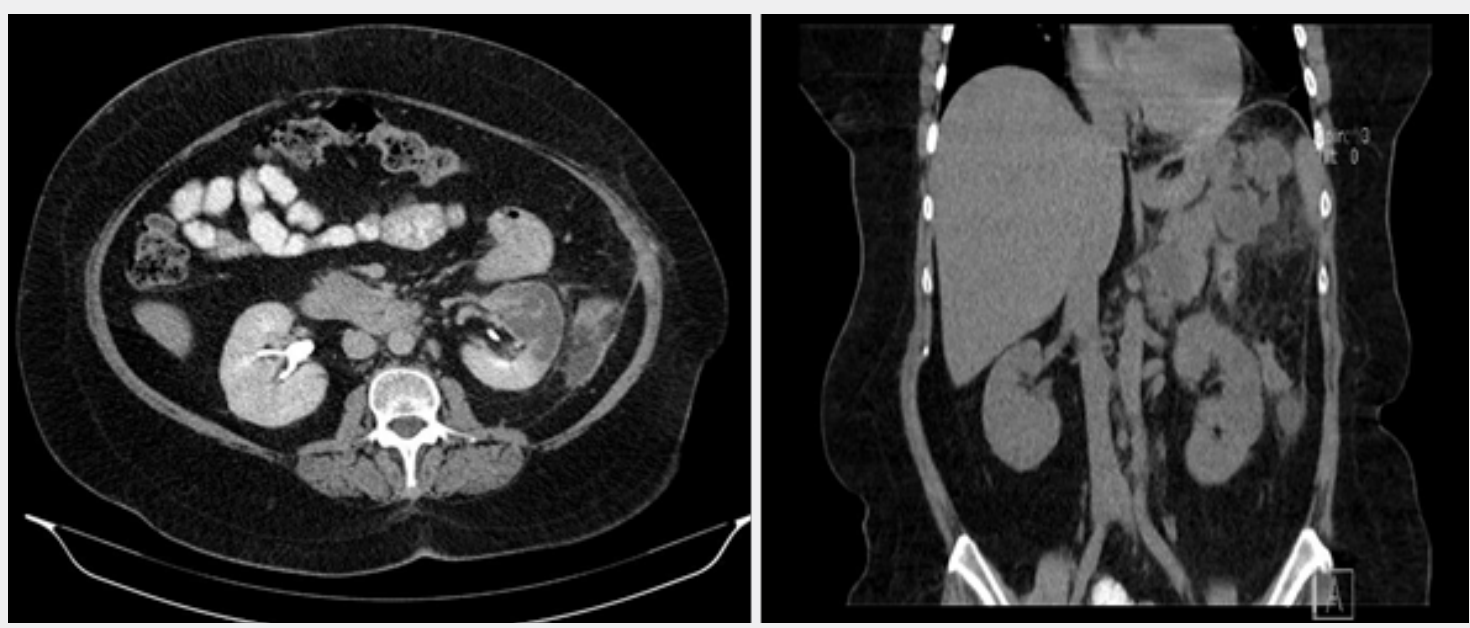

Figure 2- Abdominal control CT realized in February 2020.

Subsequent imaging tests were suggestive of unfavorable progression, especially at the expense of the increased number of secondary deposits in the lung parenchyma. The patient was referred to the Medical Oncology consultation, starting mitotane for palliation with a slow and progressive dose increase.
Suspended due to exuberant tumor recurrence at the adrenal site, with invasion of adjacent organs and structures and homolateral renal deposits and perirenal fat documented on CT performed due to complaints of abdominal pain, in August 2020 (Figure 3) (Table 3).
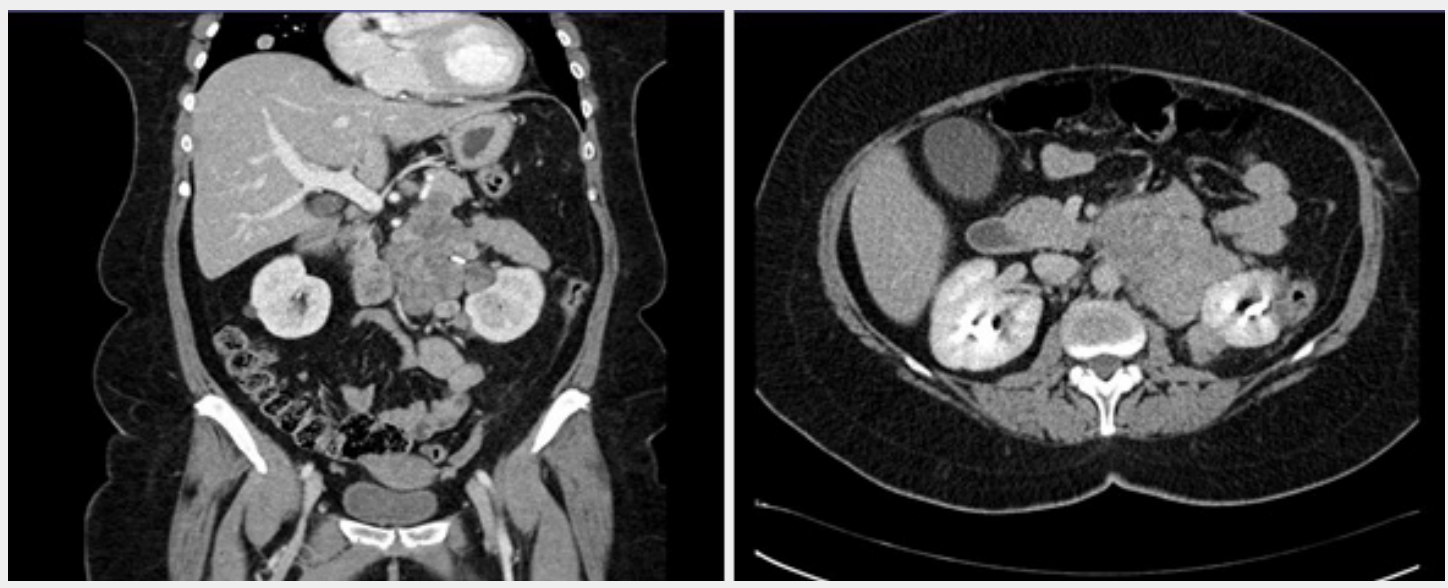

Figure 3- Abdominal CT performed due to complaints of abdominal pain, in August 2020.

Table 3: Analytical evaluation in this patient after ressection.

\begin{tabular}{|c|c|c|c|}
\hline Hormonal Evaluation & & Patient values in diagnosis & Reference Values \\
\hline Glucocorticoids & Urinary cortisol (24h) & $140 \mathrm{ug} / 24 \mathrm{~h}$ & $4.30-176.00 \mathrm{ug} / 24 \mathrm{~h}$ \\
\hline \multirow[b]{3}{*}{$\begin{array}{cc}\text { Sex } & \text { steroids } \\
\text { and } \\
\text { steroid precursors }\end{array}$} & Delta-4-androstenedione & $<0.3 \mathrm{ng} / \mathrm{mL}$ & $0.4-4.5 \mathrm{ng} / \mathrm{mL}$ \\
\hline & Dehydroepiandrostenedione sulfate (DHEA-S) & $15.05 \mathrm{ug} / \mathrm{dL}$ & $60.90-337.00 \mathrm{ug} / \mathrm{dL}$ \\
\hline & Free testosterone & $<0.5 \mathrm{pg} / \mathrm{mL}$ & $\begin{array}{c}\text { Follicular phase: } 0.20 \\
-1.70 \mathrm{ng} / \mathrm{dL} \\
\text { Ovulation: } 0.30- \\
2.30 \mathrm{ng} / \mathrm{dL} \\
\text { Luteal phase: } 0.17 \text { - } \\
1.90 \mathrm{ng} / \mathrm{dL} \\
\text { Post menopause: } \\
0.20-2.06 \mathrm{ng} / \mathrm{dL}\end{array}$ \\
\hline
\end{tabular}


The patient resumed mitotane associated with carboplatin and etoposide in September 2020, on the tenth day of chemotherapy she was admitted to the Intermediate Care unit for febrile pancytopenia, septic shock with a starting point in phlegm on the right forearm and bacteremia caused by Enterobacter and Staphylococcus aureus resistant to methicillin. After the second line treatment ceased, she was referred to the Palliative Care consultation. Having progressively worsened, she died in January 2021.

\section{Discussion}

In this article is reported the clinical case of a patient with lowgrade adrenal cortex carcinoma treated with adrenalectomy, the only potentially curative option. The laparotomic approach utilized is recommended by the literature [10]. For potentially resectable tumors, stage I to III, surgery generally requires en-bloc resection of the adjacent organs, [11] however in this patient despite the tumor dimensions, about $14 \mathrm{~cm}$, at the time of adrenalectomy, there was no invasion of the adjacent structures and the resection was complete, with free margins. Paradoxically, after one month, the presence of liver and lung metastases was verified. After seven months an extensive recurrence in the surgical site with invasion of the homolateral kidney and associated compressive symptoms, both findings are justified by the high relapse power of this tumor with probable micro metastases even in early stages [12]. The early detection of recurrence, either analytically or imagiologically, is other impacting factor in the prognosis of this neoplasia10 and may allow an intervention with a curative intent, when the lesion is unique and resectable or palliative, for multiple or unresectable injuries. The adjuvant use of mitotane is recommended by the European Society of Endocrinology for patients at high risk of histological recurrence (Ki67 greater than 10\% and high mitotic rate, more than 20 mitoses per 50 high-power fields regardless of tumor size), intraoperative rupture of the tumor capsule, invasion of the capsule or vascular and for primary treatment of unresectable lesions and recurrence [13]. Its indication in low to intermediate risk patients with resected disease is being evaluated by ADIUVO, a randomized clinical trial [14]. In extensive disease, rapidly progressive and high-grade disease it is often associated with cisplatin, doxorubicin and etoposide regimens [13].

Radiotherapy is indicated for palliation of bone metastases or locally advanced disease [15]. The presentation of CAC associated with Cushing's syndrome is associated with a poor prognosis due to frequent infectious and metabolic complications [9]. The evolution of this case, even though it was low-grade, followed the typical course of adrenal carcinomas with rapid progression, early metastasis and poor survival. In the future, molecular markers may help to define the risk of recurrence and individualize therapy, $[16,17]$ together with new treatments, like immunotherapy, may improve the outcome of CAC15. More clinical trials, such as ADIUVO, are needed to define clear indications for the use of adjuvant treatments and their impacts on the evolution of the disease. However, progress is slow and studies are scarce due to the high mortality and rarity of this neoplasia.

\section{Conclusion}

Progress is slow and studies are diminutive due to the high mortality and rarity of this neoplasia. Clinical trials can only be useful if there is cooperation between referral centers so that the sample is significant and the orientation of patients is transversal. Ideally, there should be at least one reference center in each country coordinated with the European Network for the Study of Adrenal Tumors.

\section{Consent to Participate}

Informed consent from the patient was obtained in compliance with the Helsinki Declaration.

\section{References}

1. Ng L, Libertino JM (2003) Adrenocortical carcinoma: diagnosis, evaluation and treatment. J Urol 169(1): 5-11.

2. Gicquel C, Bertagna X, Gaston V, Coste J, Louvel A, et. al (2001) Molecular markers and longterm recurrences in a large cohort of patients with sporadic adrenocortical tumors. Cancer Res 61(18): 6762-6767.

3. Sidhu S, Sywak M, Robinson B, Delbridge L (2004) Adrenocortical cancer: recent clinical and molecular advances. Curr Opin Oncol 16(1):13-8.

4. Fassnacht M, Allolio B (2009) Clinical management of adrenocortical carcinoma. Best Pract Res Clin Endocrinol Metab 23(2):273-289.

5. Maurea S, Klain M, Mainolfi C, Ziviello M, Salvatore M (2001) The diagnostic role of radionuclide imaging in evaluation of patients with nonhypersecreting adrenal masses. J Nucl Med 42(6):884-892.

6. Medeiros LJ, Weiss LM (1992). New developments in the pathologic diagnosis of adrenal cortical neoplasms. A review. Am J Clin Pathol 97(1):73-83.

7. Abiven G, Coste J, Groussin L, Anract P, Tissier F, et. al (2006) Clinical and biological features in the prognosis of adrenocortical cancer: poor outcome of cortisol-secreting tumors in a series of 202 consecutive patients. J Clin Endocrinol Metab 91(7):2650-2655.

8. Weiss LM, Medeiros LJ, Vickery AL Jr (1989) Pathologic features of prognostic significance in adrenocortical carcinoma. Am J Surg Pathol 13(3):202-206.

9. Fassnacht M, Arlt W, Bancos I, Dralle H, Newell-Price J,et. al (2016). Management of adrenal incidentalomas: European Society of Endocrinology Clinical Practice Guideline in collaboration with the European Network for the Study of Adrenal Tumors. Eur J Endocrinol 175(2):G1-G34.

10. Fassnacht M, Dekkers O, Else T, Baudin E, Berruti A, et. al (2018) European Society of Endocrinology Clinical Practice Guidelines on the management of adrenocortical carcinoma in adults, in collaboration with the European Network for the Study of Adrenal Tumors. Eur J Endocrinol 179(4), G1-G46.

11. Wängberg B, Khorram-Manesh A, Jansson S, Nilsson B, Nilsson 0 , et al (2010) The long-term survival in adrenocortical carcinoma with active surgical management and use of monitored mitotane. Endocr Relat Cancer 17(1):265-72.

12. Allolio B, Fassnacht M (2006). Clinical review: Adrenocortical carcinoma: clinical update. J Clin Endocrinol Metab 91(6):2027-37. 
13. Miller BS, Gauger PG, Hammer GD, Giordano TJ, Doherty GM. Proposal for modification of the ENSAT staging system for adrenocortical carcinoma using tumor grade. Langenbecks Arch Surg 395(7):955-61.

14. Nunes JM, Rodrigues E, Rios E, Monteiro F, Maia JC, et. al (2017) Carcinoma do Cortéx Suprarrenal: A Propósito de um Caso Clínico com Sobrevida Longa. Rev. Port Endocrinol Diabetes Metab 12(2):192-199.

15. Schteingart DE, Doherty GM, Gauger PG, Giordano TJ, Hammer $\mathrm{GD}$, et. al (2005) Management of patients with adrenal cancer recommendations of an international consensus conference. Endocr Relat Cancer 12(3):667-80.
16. de Reyniès A, Assié G, Rickman DS, Tissier F, Groussin L, et. al (2009) Gene expression profiling reveals a new classification of adrenocortical tumors and identifies molecular predictors of malignancy and survival. J Clin Oncol 27(7):1108-15.

17. Raj N, Zheng Y, Kelly V, Katz SS, Chou J, et. al (2020) PD-1 Blockade in Advanced Adrenocortical Carcinoma. J Clin Oncol 38(1):71-80.

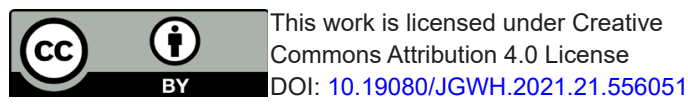

\section{Your next submission with Juniper Publishers will reach you the below assets}

- Quality Editorial service

- Swift Peer Review

- Reprints availability

- E-prints Service

- Manuscript Podcast for convenient understanding

- Global attainment for your research

- Manuscript accessibility in different formats

( Pdf, E-pub, Full Tsext, Audio)

- Unceasing customer service

Track the below URL for one-step submission https://juniperpublishers.com/online-submission.php 